University of Nebraska - Lincoln

DigitalCommons@University of Nebraska - Lincoln

Faculty Publications from the Harold W. Manter Laboratory of Parasitology

1987

BIOCHEMICAL AND IMMUNOLOGICAL SYSTEMATICS OF SOME ASCARIDOID NEMATODES: GENETIC DIVERGENCE BETWEEN CONGENERS

Steven A. Nadler

University of California - Davis, sanadler@ucdavis.edu

Follow this and additional works at: https://digitalcommons.unl.edu/parasitologyfacpubs

Part of the Parasitology Commons

Nadler, Steven A., "BIOCHEMICAL AND IMMUNOLOGICAL SYSTEMATICS OF SOME ASCARIDOID NEMATODES: GENETIC DIVERGENCE BETWEEN CONGENERS" (1987). Faculty Publications from the Harold W. Manter Laboratory of Parasitology. 700.

https://digitalcommons.unl.edu/parasitologyfacpubs/700

This Article is brought to you for free and open access by the Parasitology, Harold W. Manter Laboratory of at DigitalCommons@University of Nebraska - Lincoln. It has been accepted for inclusion in Faculty Publications from the Harold W. Manter Laboratory of Parasitology by an authorized administrator of DigitalCommons@University of Nebraska - Lincoln. 


\title{
BIOCHEMICAL AND IMMUNOLOGICAL SYSTEMATICS OF SOME ASCARIDOID NEMATODES: GENETIC DIVERGENCE BETWEEN CONGENERS
}

\author{
Steven A. Nadler* \\ Department of Microbiology, Immunology, and Parasitology, Louisiana State University Medical Center, \\ 1901 Perdido Street, New Orleans, Louisiana 70112-1393
}

ABSTRACT: Vertical starch gel electrophoresis and trefoil immunodiffusion were used to study the systematics of some ascaridoid nematodes. Within the Ascarididae, the time scale of divergence was too great for intergeneric electrophoretic comparisons. Congeneric electrophoretic comparisons of Baylisascaris procyonis (host-raccoon) versus Baylisascaris transfuga (host-black bear), and Toxocara canis (host-domestic dog) versus Toxocara cati (host-domestic cat) yielded Nei genetic distance coefficients of 1.21 and 1.55 , respectively. Estimates of times of divergence made from 1 electrophoretic clock calibration suggest that the Baylisascaris species have not shared a common ancestor for 25 million years (Myr), and that the Toxocara species diverged $33 \mathrm{Myr}$ ago. The Baylisascaris divergence estimate corresponds to host-family divergence estimates based on immunological and paleontological evidence, which suggests that cospeciation has occurred. In contrast to this, Ascaris suum (host-pig) and Ascaris lumbricoides (host-human) have a distance coefficient of 0.09 . This indicates that these species diverged comparatively recently and may represent a case of host range expansion. Trefoil immunodiffusion comparisons of ascaridoid albumins yielded reactions of identity for $A$. suum, A. lumbricoides, Parascaris equorum, B. procyonis, B. transfuga, $T$. canis, and $T$. cati. This confirms that these taxa are members of a monophyletic group.

Comparisons of proteins by electrophoretic and immunologic techniques have proven useful for estimating levels of genetic similarity and in reconstructing phylogenetic relationships among taxa (Wilson et al., 1977). Molecular data can provide a basis for analysis in groups where other methods are of limited usefulness because structural-gene and organismal-level evolution appear to be independent processes (King and Wilson, 1975; Wilson, 1976; Wilson et al., 1977). Most assessments of ascaridoid relationships have depended upon evaluation of a few qualitative characters (Hartwich, 1974; Sprent, 1980, 1983; Gibson, 1983). In the present investigation, relationships among some members of the Ascarididae sensu Sprent (1983) were studied using starch gel electrophoresis in a multilocus enzymatic approach in order to determine the systematic value of isoenzyme studies at the intergeneric and congeneric levels. In addition, an immunodiffusion study of ascaridoid albumins was undertaken to address the question of monophyly among these taxa. The results indicate that although the ascaridoid taxa examined are members of a monophyletic group, genetic di-

Received 11 June 1986; revised 8 January 1987; accepted 14 January 1987.

* Present address: Museum of Natural Science, Louisiana State University, Baton Rouge, Louisiana 70803-3216. vergence between genera and most congeners is extensive.

\section{MATERIALS AND METHODS}

Adult ascaridoids were obtained at necropsy of mammals. Taxa studied (hosts in parentheses) included: Baylisascaris procyonis (raccoon), Baylisascaris transfuga (black bear), Toxocara canis (domestic dog), Toxocara cati (domestic cat), Heterocheilus tunicatus (West Indian manatee), Ascaris suum (domestic pig), Ascaris lumbricoides (human), and Parascaris equorum (domestic horse). Living worms were rinsed in physiological saline, individually wrapped in aluminum foil to exclude air, sealed in plastic bags, and stored at $-70 \mathrm{C}$.

Preparation of tissue extracts and methods of electrophoresis have been previously described (Nadler, 1986). Homogenates of host intestinal tissue were run on some gels as controls for contamination by host or gut flora enzymes. The following buffers were used for electrophoresis: (a) phosphate-citrate, $\mathrm{pH}$ 6.8; (b) Trismaleate, $\mathrm{pH} 7.5$; (c) Tris-EDTA borate, $\mathrm{pH} 8.1$; (d) borate bridge buffer, $\mathrm{pH} 8.6$; (e) phosphate-citrate, $\mathrm{pH}$ 6.0. For details of buffer a-d compositions see Nadler (1986). Phosphate-citrate, $\mathrm{pH} 6.0$ buffer $(0.032 \mathrm{M}$ $\mathrm{Na}_{2} \mathrm{HPO}_{4}, 0.01 \mathrm{M}$ citric acid) was diluted 1:4 for gels and was undiluted for electrode bath. Following electrophoresis, specific proteins were localized in gel slices using techniques described mainly in Harris and Hopkinson (1976). Proteins studied (abbreviations in parentheses) included: sorbitol dehydrogenase (SORDH), lactate dehydrogenase (LDH), malate dehydrogenase (MDH), isocitrate dehydrogenase (ICD), 6-phosphogluconate dehydrogenase (6-PGD), glutamate dehydrogenase (GLUT), superoxide dismutase (SOD), glutamate-oxaloacetate transaminase (GOT), arginine kinase (ARG-K), adenylate kinase (ADN-K), phos- 
TABLE I. Allele frequencies for loci studied in Toxocara canis and T. cati.

\begin{tabular}{|c|c|c|c|c|c|c|c|c|c|}
\hline $\begin{array}{l}\text { Species } \\
\text { and } \\
\text { allele }\end{array}$ & & & & & us (sampl & & & & \\
\hline$T$. canis & $\begin{array}{c}\text { LDH } \\
(29)\end{array}$ & $\begin{array}{c}\text { MDH-1 } \\
(32)\end{array}$ & $\underset{(32)}{\mathrm{MDH}-2}$ & $\begin{array}{l}\text { ICD } \\
(32)\end{array}$ & $\begin{array}{c}\text { 6-PGD } \\
(28)\end{array}$ & $\begin{array}{c}\mathrm{PGM} \\
(28)\end{array}$ & $\begin{array}{c}\text { ES-D } \\
(28)\end{array}$ & $\begin{array}{l}\text { ES-1 } \\
(28)\end{array}$ & $\begin{array}{c}\text { ES-2 } \\
(28)\end{array}$ \\
\hline A & 0.724 & 1.00 & 1.00 & 0.00 & 0.00 & 0.232 & 0.982 & 0.054 & 1.00 \\
\hline B & 0.00 & 0.00 & 0.00 & 1.00 & 0.643 & 0.036 & 0.018 & 0.946 & 0.00 \\
\hline $\mathrm{C}$ & 0.276 & 0.00 & 0.00 & 0.00 & 0.357 & 0.482 & 0.00 & 0.00 & 0.00 \\
\hline D & 0.00 & 0.00 & 0.00 & 0.00 & 0.00 & 0.00 & 0.00 & 0.00 & 0.00 \\
\hline \multirow[t]{2}{*}{$E$} & 0.00 & 0.00 & 0.00 & 0.00 & 0.00 & 0.250 & 0.00 & 0.00 & 0.00 \\
\hline & $\begin{array}{l}\text { ALD } \\
(32)\end{array}$ & $\begin{array}{c}\text { ARG-K } \\
\text { (32) }\end{array}$ & $\begin{array}{c}\text { PEP-B } \\
(32)\end{array}$ & $\begin{array}{c}\text { PEP-A } \\
(32)\end{array}$ & $\begin{array}{c}\text { HEX-I } \\
\text { (32) }\end{array}$ & $\begin{array}{l}\text { MPI } \\
(11)\end{array}$ & $\begin{array}{c}\text { GOT-1 } \\
(32)\end{array}$ & $\begin{array}{c}\text { GLUT } \\
(32)\end{array}$ & $\underset{(32)}{\text { SORDH }}$ \\
\hline A & 1.00 & 1.00 & 0.00 & 1.00 & 1.00 & 0.682 & 1.00 & 1.00 & 1.00 \\
\hline B & 0.00 & 0.00 & 0.00 & 0.00 & 0.00 & 0.318 & 0.00 & 0.00 & 0.00 \\
\hline C & 0.00 & 0.00 & 0.00 & 0.00 & 0.00 & 0.00 & 0.00 & 0.00 & 0.00 \\
\hline $\mathrm{D}$ & 0.00 & 0.00 & 0.00 & 0.00 & 0.00 & 0.00 & 0.00 & 0.00 & 0.00 \\
\hline E & 0.00 & 0.00 & 1.00 & 0.00 & 0.00 & 0.00 & 0.00 & 0.00 & 0.00 \\
\hline T. cati & $\begin{array}{l}\text { LDH } \\
(22)\end{array}$ & $\begin{array}{c}\text { MDH-1 } \\
(22)\end{array}$ & $\underset{(22)}{\mathrm{MDH}-2}$ & $\begin{array}{l}\text { ICD } \\
(22)\end{array}$ & $\begin{array}{c}\text { 6-PGD } \\
(22)\end{array}$ & $\begin{array}{c}\text { PGM } \\
(22)\end{array}$ & $\begin{array}{c}\text { ES-D } \\
(22)\end{array}$ & $\begin{array}{l}\text { ES-1 } \\
(19)\end{array}$ & $\begin{array}{l}\text { ES-2 } \\
(14)\end{array}$ \\
\hline A & 0.00 & 1.00 & 0.00 & 1.00 & 1.00 & 0.00 & 0.023 & 0.316 & 0.107 \\
\hline B & 1.00 & 0.00 & 1.00 & 0.00 & 0.00 & 0.00 & 0.114 & 0.684 & 0.821 \\
\hline $\mathrm{C}$ & 0.00 & 0.00 & 0.00 & 0.00 & 0.00 & 0.00 & 0.864 & 0.00 & 0.036 \\
\hline $\mathrm{D}$ & 0.00 & 0.00 & 0.00 & 0.00 & 0.00 & 0.977 & 0.00 & 0.00 & 0.036 \\
\hline$E$ & 0.00 & 0.00 & 0.00 & 0.00 & 0.00 & 0.00 & 0.00 & 0.00 & 0.00 \\
\hline $\mathrm{F}$ & 0.00 & 0.00 & 0.00 & 0.00 & 0.00 & 0.023 & 0.00 & 0.00 & 0.00 \\
\hline G & 0.00 & 0.00 & 0.00 & 0.00 & 0.00 & 0.00 & 0.00 & 0.00 & 0.00 \\
\hline \multirow[t]{2}{*}{$\mathrm{H}$} & 0.00 & 0.00 & 0.00 & 0.00 & 0.00 & 0.00 & 0.00 & 0.00 & 0.00 \\
\hline & $\underset{(22)}{\text { ALD }}$ & $\begin{array}{c}\text { ARG-K } \\
(22)\end{array}$ & $\begin{array}{c}\text { PEP-B } \\
(22)\end{array}$ & $\begin{array}{c}\text { PEP-A } \\
(22)\end{array}$ & $\begin{array}{c}\text { HEX-I } \\
(22)\end{array}$ & $\begin{array}{c}\text { MPI } \\
(8)\end{array}$ & $\begin{array}{c}\text { GOT-1 } \\
(22)\end{array}$ & $\begin{array}{c}\text { GLUT } \\
(22)\end{array}$ & $\underset{(22)}{\text { SORDH }}$ \\
\hline A & 0.00 & 1.00 & 0.023 & 0.00 & 0.023 & 0.313 & 0.00 & 0.00 & 0.00 \\
\hline B & 1.00 & 0.00 & 0.182 & 1.00 & 0.932 & 0.688 & 1.00 & 1.00 & 1.00 \\
\hline C & 0.00 & 0.00 & 0.227 & 0.00 & 0.045 & 0.00 & 0.00 & 0.00 & 0.00 \\
\hline D & 0.00 & 0.00 & 0.114 & 0.00 & 0.00 & 0.00 & 0.00 & 0.00 & 0.00 \\
\hline $\mathrm{E}$ & 0.00 & 0.00 & 0.091 & 0.00 & 0.00 & 0.00 & 0.00 & 0.00 & 0.00 \\
\hline$F$ & 0.00 & 0.00 & 0.091 & 0.00 & 0.00 & 0.00 & 0.00 & 0.00 & 0.00 \\
\hline G & 0.00 & 0.00 & 0.227 & 0.00 & 0.00 & 0.00 & 0.00 & 0.00 & 0.00 \\
\hline $\mathbf{H}$ & 0.00 & 0.00 & 0.045 & 0.00 & 0.00 & 0.00 & 0.00 & 0.00 & 0.00 \\
\hline
\end{tabular}

phoglucomutase (PGM), esterase D (ES-D), $\alpha$-naphthyl acetate esterase (ES-1), $\beta$-naphthyl acetate esterase (ES-2), peptidase A (PEP-A), peptidase B (PEP-B), peptidase D (PEP-D), aldolase (ALD), mannose-6-phosphate isomerase (MPI), hexose isomerase (HEX-I), and hemoglobin (HB). Peptidase substrates were valyl-leucine for peptidase A, leucyl-glycyl-glycine for peptidase $\mathrm{B}$, and phenylalanyl-proline for peptidase D. $\alpha$-Naphthyl acetate and $\beta$-naphthyl acetate were used as substrates for esterase- 1 and esterase- 2 , respectively. Modifications of some staining procedures and methods of scoring gels are described in Nadler (1986). Presumed genotypes for individuals at all loci were entered into the BIOSYS-1 computer program of Swofford and Selander (1981) and analyzed.

To isolate albumin for antiserum production, proteins in pooled $A$. suum pseudocoelomic fluid samples were separated by preparative starch gel electrophoresis in buffer b. Proteins in gel slices were visualized under ultraviolet light as fluorescent bands following incubation of gel slices in $0.003 \%$ 1-anilino-naphthalene sulfonate in $0.1 \mathrm{M}$ sodium phosphate buffer, $\mathrm{pH}$ 6.8 (Hartman and Udenfriend, 1969). Ascaris suum albumin, a protein previously described on the basis of its solubility properties (Cavier and Savel, 1951), was the protein of greatest relative concentration on gel slices. This band was cut from the gel, freeze-thawed, eluted by centrifugation in a Hemmings filter apparatus, and concentrated by vacuum filtration. Isolated albumin migrated as a single band upon cellulose polyacetate electrophoresis in buffer $\mathrm{d}$.

For antiserum production, a New Zealand white rabbit was challenged with 6 injections of albumin over an 8 -wk period. The first 2 injections were subcutaneous, and each was composed of $5 \mathrm{mg}$ albumin in 1 $\mathrm{ml}$ saline, emulsified in $1 \mathrm{ml}$ of complete Freund's adjuvant. The final 4 injections each consisted of 2-3 $\mathrm{mg}$ of albumin in $0.5 \mathrm{ml}$ saline given intravenously. Serum was collected 10 days after the final injection.

Immunodiffusion comparisons of albumins were performed on plates of trefoil design in which antibody concentrations are maximized. Details of technical procedures and processing are described in Goodman and Moore (1971). Trefoil agarose segments were washed and stained by the methods of Schwaner and Dessauer (1981). Levels of albumin divergence were 
TABLE II. Allele frequencies for loci studied in Baylisascaris procyonis and B. transfuga.

\begin{tabular}{|c|c|c|c|c|c|c|c|c|c|}
\hline $\begin{array}{l}\text { Species } \\
\text { and } \\
\text { allele }\end{array}$ & \multicolumn{9}{|c|}{ Locus (sample size) } \\
\hline $\begin{array}{l}\text { B. pro- } \\
\text { cyonis }\end{array}$ & $\underset{(3)}{\text { LDH }}$ & $\underset{\text { (3) }}{\mathrm{MDH}-1}$ & $\underset{\text { (3) }}{\mathrm{MDH}-2}$ & $\begin{array}{c}\text { 6-PGD } \\
\text { (3) }\end{array}$ & $\begin{array}{c}\text { ES-D } \\
(3)\end{array}$ & $\begin{array}{c}\text { ES-1 } \\
(3)\end{array}$ & $\underset{\text { (3) }}{\text { GOT-1 }}$ & $\underset{(3)}{\text { SORDH }}$ & $\begin{array}{c}\text { PEP-A } \\
\text { (3) }\end{array}$ \\
\hline A & 1.00 & 0.00 & 0.00 & 0.00 & 0.00 & 0.00 & 1.00 & 0.00 & 1.00 \\
\hline B & 0.00 & 1.00 & 1.00 & 0.00 & 1.00 & 1.00 & 0.00 & 1.00 & 0.00 \\
\hline \multirow[t]{2}{*}{ C } & 0.00 & 0.00 & 0.00 & 1.00 & 0.00 & 0.00 & 0.00 & 0.00 & 0.00 \\
\hline & $\begin{array}{c}\text { PEP-B } \\
\text { (3) }\end{array}$ & $\begin{array}{c}\text { HEX-I } \\
\text { (3) }\end{array}$ & $\begin{array}{c}\text { ALD } \\
(3)\end{array}$ & $\begin{array}{c}\text { MPI } \\
(3)\end{array}$ & $\begin{array}{c}\text { PEP-D } \\
\text { (3) }\end{array}$ & $\begin{array}{c}\text { SOD-1 } \\
\text { (3) }\end{array}$ & $\underset{\text { (3) }}{\mathrm{SOD}-2}$ & $\begin{array}{c}\text { PGM } \\
(3)\end{array}$ & $\underset{(3)}{\mathrm{HB}}$ \\
\hline A & 0.00 & 1.00 & 1.00 & 0.00 & 1.00 & 1.00 & 1.00 & 1.00 & 1.00 \\
\hline B & 1.00 & 0.00 & 0.00 & 0.00 & 0.00 & 0.00 & 0.00 & 0.00 & 0.00 \\
\hline $\mathrm{C}$ & 0.00 & 0.00 & 0.00 & 1.00 & 0.00 & 0.00 & 0.00 & 0.00 & 0.00 \\
\hline$\underset{\text { transfuga }}{\text { B. }}$ & $\begin{array}{c}\text { LDH } \\
(3)\end{array}$ & $\begin{array}{c}\text { MDH-1 } \\
\text { (3) }\end{array}$ & $\underset{\text { (3) }}{\mathrm{MDH}-2}$ & $\begin{array}{c}\text { 6-PGD } \\
\text { (3) }\end{array}$ & $\begin{array}{c}\text { ES-D } \\
(3)\end{array}$ & $\begin{array}{c}\text { ES-1 } \\
(3)\end{array}$ & $\begin{array}{c}\text { GOT-1 } \\
\text { (3) }\end{array}$ & $\underset{(3)}{\text { SORDH }}$ & $\begin{array}{c}\text { PEP-A } \\
\text { (3) }\end{array}$ \\
\hline A & 1.00 & 1.00 & 1.00 & 0.167 & 1.00 & 1.00 & 1.00 & 1.00 & 0.00 \\
\hline B & 0.00 & 0.00 & 0.00 & 0.833 & 0.00 & 0.00 & 0.00 & 0.00 & 1.00 \\
\hline \multirow[t]{2}{*}{$\mathrm{C}$} & 0.00 & 0.00 & 0.00 & 0.00 & 0.00 & 0.00 & 0.00 & 0.00 & 0.00 \\
\hline & $\begin{array}{c}\text { PEP-B } \\
(3)\end{array}$ & $\underset{(3)}{\text { HEX-I }}$ & $\underset{(3)}{\text { ALD }}$ & $\begin{array}{c}\text { MPI } \\
(3)\end{array}$ & $\underset{(3)}{\text { PEP-D }}$ & $\begin{array}{c}\text { SOD-1 } \\
\text { (3) }\end{array}$ & $\begin{array}{c}\text { SOD-2 } \\
\text { (3) }\end{array}$ & $\begin{array}{c}\text { PGM } \\
(3)\end{array}$ & $\begin{array}{l}\text { HB } \\
(3)\end{array}$ \\
\hline A & 1.00 & 1.00 & 0.00 & 0.167 & 0.00 & 0.00 & 1.00 & 0.00 & 1.00 \\
\hline B & 0.00 & 0.00 & 1.00 & 0.667 & 0.667 & 1.00 & 0.00 & 1.00 & 0.00 \\
\hline $\mathrm{C}$ & 0.00 & 0.00 & 0.00 & 0.167 & 0.333 & 0.00 & 0.00 & 0.00 & 0.00 \\
\hline
\end{tabular}

assessed by comparing reactions of the homologous species antigen versus a test species antigen. Experiments were repeated at least 3 times using dilutions of pseudocoelomic fluid and saline extracts of whole worm tissues as antigen. Dilutions of 1 part pseudocoelomic fluid to 500 parts diluent $(0.9 \%$ saline with $0.01 \%$ thimerosal as a bacteriostatic agent) or 1 part saline tissue extract to 100 parts diluent yielded reactions of equivalence. Antigens from both sources reacted identically. Antiserum was used undiluted.

\section{RESULTS}

\section{Comparative electrophoresis}

Multilocus electrophoretic comparisons of $P$. equorum, $A$. suum, T. canis, $H$. tunicatus, and $B$. procyonis revealed that intergeneric comparisons would be of limited usefulness because the genera had electromorphs of different mobility at most loci tested. These included: SORDH, LDH, MDH-1, MDH-2, 6-PGD, GLUT, GOT-1, PGM, ES-D, ES-1, PEP-B, ALD, and HEX-I. Three pairs of congeners were studied at 18 genetic loci: $T$. canis and $T$. cati; B. procyonis and $B$. transfuga; and $A$. suum and $A$. lumbricoides. Tables I-III summarize the loci surveyed, number of alleles per locus, allele frequencies, and number of individuals surveyed. Differences in the resolution or activities of loci in the different taxa prohibited surveying identical proteins in the 3 genera. No evidence for host or gut flora enzyme contamination was found.
Nei (1972) genetic distance coefficients for $B$. procyonis (host-raccoon) versus $B$. transfuga (host-black bear), and T. canis (host-domestic dog) versus $T$. cati (host-domestic cat) were 1.21 and 1.55 , respectively. An estimate that takes into account the proportion of slow- to fastevolving loci in the data set (Sarich, 1977) suggests that $B$. procyonis and $B$. transfuga diverged $25 \mathrm{Myr}$ ago, and that $T$. canis and $T$. cati diverged $33 \mathrm{Myr}$ ago.

In contrast to this, $A$. suum (host-pig) and $A$. lumbricoides (host-human) have a Nei distance coefficient of 0.09. Based upon this distance coefficient, it is estimated that slightly less than 1 Myr has elapsed since these 2 species diverged.

\section{Comparative immunodiffusion}

Because of these large genetic distances, and to investigate the question of monophyly, a comparative study of ascaridoid albumins was undertaken using the antiserum raised to purified $A$. suum albumin. Homologous trefoil comparisons of $P$. equorum, T. canis, T. cati, B. procyonis, $B$. transfuga, and $A$. lumbricoides yielded reactions of identity between the antigen wells (Fig. 1A-D, F-H). These reactions indicate that there is no detectable divergence between the antigens. In contrast, the homologous comparison of $\boldsymbol{H}$. tunicatus yielded a reaction of noni- 
TABLE III. Allele frequencies for loci studied in Ascaris suum and A. lumbricoides.

\begin{tabular}{|c|c|c|c|c|c|c|c|c|c|}
\hline $\begin{array}{l}\text { Species } \\
\text { and } \\
\text { allele }\end{array}$ & \multicolumn{9}{|c|}{ Locus (sample size) } \\
\hline A. suum & $\underset{(4)}{\mathrm{LDH}}$ & $\begin{array}{c}\text { MDH-1 } \\
\text { (4) }\end{array}$ & $\underset{\text { (4) }}{\mathrm{MDH}-2}$ & $\begin{array}{c}\text { 6-PGD } \\
\text { (4) }\end{array}$ & $\begin{array}{c}\text { ES-D } \\
(4)\end{array}$ & $\begin{array}{c}\text { ES-1 } \\
(4)\end{array}$ & $\begin{array}{c}\text { GOT-1 } \\
(4)\end{array}$ & $\begin{array}{c}\text { GOT-2 } \\
\text { (4) }\end{array}$ & $\begin{array}{c}\text { SORDH } \\
\text { (4) }\end{array}$ \\
\hline A & 1.00 & 1.00 & 1.00 & 0.500 & 1.00 & 1.00 & 1.00 & 1.00 & 1.00 \\
\hline \multirow[t]{2}{*}{ B } & 0.00 & 0.00 & 0.00 & 0.500 & 0.00 & 0.00 & 0.00 & 0.00 & 0.00 \\
\hline & $\underset{(4)}{\text { PEP-A }}$ & $\begin{array}{l}\text { PEP-B } \\
(4)\end{array}$ & $\begin{array}{c}\text { HEX-I } \\
(4)\end{array}$ & $\underset{(4)}{\text { ALD }}$ & $\begin{array}{c}\text { ICD } \\
(4)\end{array}$ & $\begin{array}{c}\text { MPI } \\
(2)\end{array}$ & $\underset{(4)}{A D N-K}$ & $\begin{array}{c}\text { PEP-D } \\
(4)\end{array}$ & $\underset{(4)}{S O D-1}$ \\
\hline A & 1.00 & 1.00 & 1.00 & 1.00 & 1.00 & 0.500 & 1.00 & 1.00 & 1.00 \\
\hline B & 0.00 & 0.00 & 0.00 & 0.00 & 0.00 & 0.500 & 0.00 & 0.00 & 0.00 \\
\hline $\begin{array}{c}A . \\
\text { lumbri- } \\
\text { coides }\end{array}$ & $\underset{(2)}{\mathrm{LDH}}$ & $\underset{(2)}{\text { MDH-1 }}$ & $\underset{(2)}{\mathrm{MDH}-2}$ & $\begin{array}{c}\text { 6-PGD } \\
\text { (2) }\end{array}$ & $\begin{array}{c}\text { ES-D } \\
(2)\end{array}$ & $\begin{array}{c}\text { ES-1 } \\
(2)\end{array}$ & $\underset{(2)}{\text { GOT-1 }}$ & $\underset{(2)}{\text { GOT-2 }}$ & $\underset{\text { (2) }}{\text { SORDH }}$ \\
\hline A & 1.00 & 1.00 & 1.00 & 0.00 & 1.00 & 1.00 & 1.00 & 1.00 & 1.00 \\
\hline \multirow[t]{2}{*}{ B } & 0.00 & 0.00 & 0.00 & 1.00 & 0.00 & 0.00 & 0.00 & 0.00 & 0.00 \\
\hline & $\begin{array}{c}\text { PEP-A } \\
(2)\end{array}$ & $\begin{array}{l}\text { PEP-B } \\
\text { (2) }\end{array}$ & $\begin{array}{l}\text { HEX-I } \\
\text { (2) }\end{array}$ & $\begin{array}{l}\text { ALD } \\
(2)\end{array}$ & $\underset{(2)}{\text { ICD }}$ & $\begin{array}{c}\text { MPI } \\
(2)\end{array}$ & $\underset{(2)}{A D N-K}$ & $\begin{array}{l}\text { PEP-D } \\
(2)\end{array}$ & $\begin{array}{c}\text { SOD-1 } \\
(2)\end{array}$ \\
\hline A & 1.00 & 1.00 & 1.00 & 1.00 & 1.00 & 0.00 & 1.00 & 1.00 & 0.00 \\
\hline B & 0.00 & 0.00 & 0.00 & 0.00 & 0.00 & 1.00 & 0.00 & 0.00 & 1.00 \\
\hline
\end{tabular}

dentity (Fig. 1E). Such a reaction occurs when antigens of the test species are not recognized by the antiserum.

\section{DISCUSSION}

Genetic divergence between some representative genera of the Ascarididae sensu Sprent (1983) is so great that comparative enzyme electrophoresis fails to reveal similarities between taxa. This level of protein divergence prohibits cladistic analysis of the data, and suggests that isoenzyme studies are not appropriate for the analysis of phylogenetic relationships in the superfamily Ascaridoidea. Such divergence is indicative of an ancient separation of these genera. Despite this dissimilarity at the electrophoretic level, albumin immunodiffusion reactions of identity suggest that $A$. lumbricoides, $A$. suum, $P$. equorum, B. procyonis, B. transfuga, $T$. canis, and $T$. cati are members of a monophyletic group. In contrast to this, the nonidentity of $\boldsymbol{H}$. tunicatus albumin indicates that its antigenic sites are not recognized by the antibody or that this organism has no albumin. This result suggests that additional studies of this taxon are necessary.

The Baylisascaris and Toxocara congeners had very large genetic distances for species of the same genus. However, such distances would be expected if the relationships of these species reflect host divergence dates. For example, albumin and transferrin immunological distance data suggest that the Ursus-Procyon (bear-raccoon) divergence occurred approximately $25 \mathrm{Myr}$ ago (Sarich, 1973). Paleontological evidence also indicates that the Procyonidae and Ursidae have not shared a common ancestor since the Miocene (Romer, 1966). Albumin distance data also indicate that the canoid-feloid divergence occurred approximately 52 Myr ago (Sarich, 1969), which is in agreement with the paleontological evidence indicating an Eocene Canidae-Felidae separation (Romer, 1966).

Estimates of time of divergence made from electrophoretic data can vary considerably depending on the time-distance calibration employed. The most reasonable estimates take into account the proportion of slow- to fast-evolving loci in the data set (Sarich, 1977). With such a calibration, the Baylisascaris divergence date of $25 \mathrm{Myr}$ ago corresponds to the host-family divergence date. This agreement between host and parasite divergence dates could be the result of cospeciation.

For $T$. canis and $T$. cat $i$, the data suggest that these species shared a common ancestor after the canoid-feloid divergence. However, because these times of divergence are approximations, and the genetic distances are so large, the most sound conclusion is that, like the Baylisascaris species, the Toxocara congeners represent an ancient speciation event.

Large genetic distances are not restricted to 


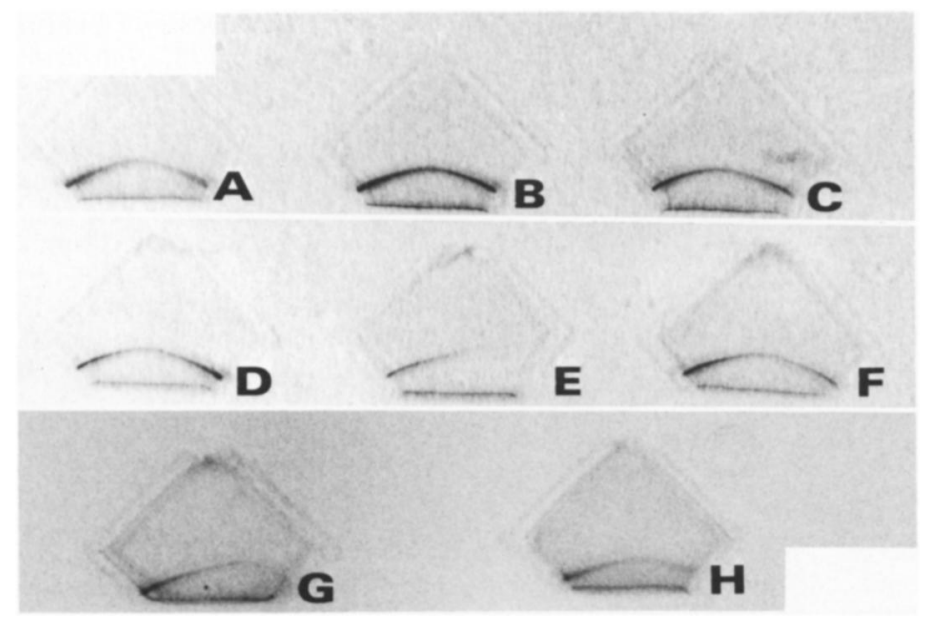

FIGURE 1. Homologous trefoil plate reactions of ascaridoid albumins: (A) T. canis, (B) A. suum, (C) $P$. equorum, (D) B. procyonis, (E) H. tunicatus, (F) T. cati, (G) A. lumbricoides, and (H) B. transfuga.

ascaridoid congeners parasitizing phylogenetically distant hosts. The sibling species $P$. equorum and Parascaris univalens of equines have a Nei genetic distance coefficient of 1.94 (Bullini et al., 1978). These 2 species, which have different diploid chromosome numbers, apparently became reproductively isolated after $P$. univalens gave rise to $P$. equorum by tetraploidization (Goday and Pimpinelli, 1984).

In contrast to this, $A$. suum and $A$. lumbricoides have a very small genetic distance. In the present study, 14 loci that were monomorphic in A. suum were of identical electrophoretic mobility in $A$. lumbricoides. Three polymorphic loci had shared alleles in the 2 species. Only 1 enzymatic locus (SOD-1) was of different electrophoretic mobility. This locus is apparently monomorphic in A. suum (Leslie et al., 1982), however, further studies are necessary to confirm the diagnostic nature of this locus.

In a study of 21 protein loci in $A$. lumbricoides and $A$. suum, Nascetti et al. (1979) reported that 4 loci were of different electrophoretic mobility in these species. These loci were malate dehydrogenase-3, glucose-6-phosphate dehydrogenase, esterase-2, and aldolase. One locus, phosphoisomerase, was considered to be partially diagnostic. Superoxide dismutase was not evaluated by these investigators. In the present study, aldolase and $\alpha$-naphthyl acetate esterase electromorphs were of identical mobility in these 2 species. Glucose-6-phosphate dehydrogenase and malic enzyme (presumably MDH-3 of Nascetti et al., 1979) activities were not adequately resolved for interpretation. Possibly, some protein-charge differences went undetected in the present study. On the other hand, genetic differences between the samples used in these studies could also account for the different results.

Despite these experimental differences, the Nei distance coefficient of 0.09 and divergence estimate reported in the present study is comparable to the 0.315 Nei coefficient arrived at by Nascetti et al. (1979). These authors estimated time of divergence to be $1.6 \mathrm{Myr}$ ago for these species. These distance coefficients and divergence dates are in obvious conflict with established host phylogenetic relationships, and suggest that host range expansion has occurred. Opportunities for crossinfection may have been enhanced because of the physiological similarities between humans and pigs and by pig domestication.

Many previous studies of ascaridoid systematics have focused on the validity of the distinction between $A$. suum and $A$. lumbricoides (see Gibson, 1983 for review). Nascetti et al. (1979) were the first to demonstrate that $A$. suum and A. lumbricoides are genetically distinct species. The current study, along with the immunoelectrophoretic findings of Kurimoto (1974), support the hypothesis that $A$. suum and $A$. lumbricoides are sibling species.

\section{ACKNOWLEDGMENTS}

I thank Drs. Joseph H. Miller and Herbert C. Dessauer for their assistance. I am indebted to 
the following individuals for their help in collecting specimens: Drs. C. Beck, N. Chia, J. Crum, T. Klei, B. Stewart, and A. Voors. This research was supported in part by a Grant-in-Aid of Research from Sigma Xi, the Scientific Research Society.

\section{LITERATURE CITED}

Bullini, L., G. NASCetti, S. Ciafrè, F. Rumore, E. Biocca, S. Montalenti, AND G. Rita. 1978. Ricerche cariologiche ed elettroforetiche su Parascaris univalens e Parascaris equorum. Atti della Accademia Nazionale dei Lincei Rendiconti Classe di Scienze Fisiche Matematiche e Naturali 65: 151156.

Cavier, R., ANd J. Savel. 1951. Sur la composition chimique du liquide coelomique de l'ascaris du porc, Ascaris lumbricoides, Linné 1758. Bulletin de la Societe Chimique de France 33: 455-460.

Gibson, D. I. 1983. The systematics of ascaridoic nematodes-A current assessment. In Systematics association special volume no. 22. Concepts in nematode systematics, A. R. Stone, H. M. Platt, and L. F. Khalil (eds.). Academic Press, New York, pp. 321-338.

Goday, C., ANd S. Pimpinelli. 1984. Chromosome organization and heterochromatin elimination ir Parascaris. Science 224: 411-413.

$\rightarrow$ GOODMAN, M., AND G. W. MOORE. 1971. Immunodiffusion systematics of the primates. I. Catarrhini. Systematic Zoology 20: 19-62.

Harris, H., AND D. A. HoPKINSON. 1976. Handbook of enzyme electrophoresis in human genetics. North-Holland Publishing Company, Amsterdam.

Hartman, B. K., AND S. Udenfriend. 1969. A method for immediate visualization of proteins in acrylamide gels and its use for preparation of antibodies to enzymes. Analytical Biochemistry 30: 391-394.

HaRTwich, G. 1974. Keys to genera of the Ascaridoidea. In CIH keys to the nematode parasites of vertebrates, R. C. Anderson, A. G. Chabaud, and S. M. Willmott (eds.). Commonwealth Agricultural Bureaux, Farnham Royal, pp. 1-15.

KING, M., AND A. C. WILSON. 1975. Evolution at two levels in humans and chimpanzees. Science 188: 107-116.

KuRIMOTO, H. 1974. Morphological, biochemical and immunological studies on the differences between
Ascaris lumbricoides, Linnaeus, 1758 and Ascaris suum Goeze, 1782. Japanese Journal of Parasitology 23: 251-267.

Leslie, J. F., G. D. Cain, G. K. MefFe, and R. C. VRIJENHOEK. 1982. Enzyme polymorphism in Ascaris suum (Nematoda). Journal of Parasitology 68: $576-587$.

NADLER, S. A. 1986. Biochemical polymorphism in Parascaris equorum, Toxocara canis and Toxocara cati. Molecular and Biochemical Parasitology 18: $45-54$.

Nascetti, G., C. Grappelli, L. Bullini, and S. G. MONTALENTI. 1979. Ricerche sul differenziamento genetico di Ascaris lumbricoides e Ascaris suum. Atti della Accademia Nazionale dei Lincei Rendiconti Classe di Scienze Fisiche Matematiche e Naturali 67: 457-465.

NEI, M. 1972. Genetic distance between populations. American Naturalist 106: 283-292.

ROMER, A. S. 1966 . Vertebrate paleontology, 3rd ed. University of Chicago Press, Chicago, $468 \mathrm{p}$.

SARICH, V. M. 1969. Pinniped phylogeny. Systematic Zoology 18: 416-422.

. 1973. The giant panda is a bear. Nature 245: 218-220.

. 1977. Rates, sample sizes, and the neutrality hypothesis for electrophoresis in evolutionary studies. Nature 265: 24-28.

Schwaner, T. D., and H. C. Dessauer. 1981. Immunological evidence for the relationships of Papuan boids. Journal of Herpetology 15: 250-253.

SPRENT, J. F. A. 1980. Supplementary review article: Ascaridoid nematodes of sirenians-The Heterocheilinae redefined. Journal of Helminthology 54: 309-327.

- 1983. Observations on the systematics of Ascaridoid nematodes. In Systematics association special volume no. 22. Concepts in nematode systematics, A. R. Stone, H. M. Platt, and L. F. Khalil (eds.). Academic Press, New York, pp. 303-319.

Swofford, D. L., AND R. B. Selander. 1981. BIOSYS-1: A FORTRAN program for the comprehensive analysis of electrophoretic data in population genetics and systematics. Journal of Heredity 72: 281-283.

WILSON, A. C. 1976. Gene regulation in evolution. In Molecular evolution, F. J. Ayala (ed.). Sinauer Associates, Sunderland, Massachusetts, pp. 225234.

- S. S. Carlson, and T. J. White. 1977. Biochemical evolution. Annual Review of Biochemistry 46: 573-639. 